\title{
Brain Microglia/Macrophages Express Neurotrophins that Selectively Regulate Microglial Proliferation and Function
}

\author{
Stella Elkabes, Emanuel M. DiCicco-Bloom, and Ira B. Black \\ Department of Neuroscience and Cell Biology, Robert Wood Johnson Medical School, UMDNJ, Piscataway, \\ New Jersey 08854
}

\begin{abstract}
Although microglia-mediated cytotoxicity has been extensively investigated, little is known about the potential microglial role in neuronal and glial support. Characterization of trophin elaboration by microglia and identification of responsive populations may define novel functions. We now report that microglia/brain macrophages express neurotrophins of the nerve growth factor (NGF) gene family in vitro and in vivo, suggesting that these cells promote development and normal function of neurons and glia. Moreover, neurotrophins promote microglial proliferation and phagocytic activity in vitro.

We found that microglia express neurotrophins in a regionspecific manner and that within any region only subpopulations elaborate trophins. Using an antiserum specific for neurotrophin-3 (NT-3) with the microglial/macrophage marker OX-42 on postnatal day 10 in vivo, double-labeled cells were identified in the cerebral cortex, globus pallidus, and medulla; NT-3 was undetectable in OX-42-positive cells in the ependyma, the external capsule, cho-
\end{abstract}

roid plexus, and meninges. In contrast, ramified microglia in the adult brain did not exhibit NT-3 immunoreactivity, suggesting developmental regulation of microglial NT-3 expression. In situ hybridization studies on purified microglial cultures confirmed that only subpopulations express the NGF and NT-3 genes, substantiating the existence of microglial heterogeneity. We tentatively conclude that microglial subtypes serve trophic roles in the normal brain, in addition to exerting well documented deleterious actions in illness and injury.

Microglia were also responsive to neurotrophins: brainderived neurotrophic factor (BDNF) and NT-3 increased $\left[{ }^{3} \mathrm{H}\right]$ thymidine incorporation in vitro, and NT-3 promoted proliferation. Moreover, NT-3 induced phagocytic activity, suggesting that the factor plays a role in processes associated with cellular activation.

Key words: injury; inflammation; reactive gliosis; trophic factors; mitosis; phagocytosis
Extensive evidence indicates that microglia/brain macrophages are involved in brain function, especially in neuropathological conditions (for review, see Dickson et al., 1993; McGeer et al., 1993). Resident resting microglia are activated in response to injury, infection, and inflammation of the nervous system. Activated microglia proliferate, exhibit phagocytic activity disposing of degenerating elements (Fulcrand and Privat, 1977; Murabe et al., 1981; Giulian et al., 1989; Stoll et al., 1989), and secrete cytotoxic agents that induce death of neurons and demyelination of oligodendrucytes (Giulian, 1990; Thery et al., 1991; Zajicek et al., 1992; Giulian et al., 1993).

In contrast, microglia are also sources of growth factors such as transforming growth factor- $\beta$ (TGF- $\beta$ ), platelet-derived growth factor (PDGF), epidermal growth factor (EGF), insulin-like growth factors, and basic fibroblast growth factor (bFGF), suggesting that these cells potentially provide trophic support for glia and neurons (Rappolee et al., 1988; Shimojo et al., 1991). Secretion of nerve growth factor (NGF) by activated brain macrophages has also been reported (Mallat et al., 1989). Recent studies have indicated that microglial conditioned medium promotes survival and development of mesencephalic neurons and stimu-

\footnotetext{
Received Sept. 13, 1995; revised Jan. 11, 1996; accepted Feb. 5, 1996.

This work was supported by National Institutes of Health Grant POI HD 2331506A1 and by Trophix Pharmaceuticals Inc. We thank Drs. Howard T. J. Mount, Ann C. Sherwood, and Evan Wolf for helpful discussions and suggestions.

Correspondence should be addressed to Dr. Stella Elkabes, Neuroscience and Cell Biology, Robert Wood Johnson Medical School, UMDNJ, 675 Hoes Lane, Piscataway, NJ 08854.

Copyright $C 1996$ Society for Neuroscience $0270-6474 / 96 / 162508-14 \$ 05.00 / 0$
}

lates myelination in vitro (Nagata et al., 1993; Hamilton and Leonard, 1994).

Although the cytotoxic effects of microglia have been studied extensively, microglial support of neurons and glia is not well defined. To begin investigating the role of microglia in the development and survival of neuronal and non-neuronal cells, we have studied expression of neurotrophins (Barde et al., 1982; Ernfors et al., 1990; Hohn et al., 1990; Maisonpierre et al., 1990; Berkemeier et al., 1991) in vivo and in vitro. We focused on these trophic factors because their involvement in the development and growth of the CNS has been well documented. Neurotrophins participate in multiple developmental processes ranging from survival of neurons (Levi-Montalcini and Angeletti, 1968; Thoenen and Barde, 1980; Hamburger et al., 1981; Collazo et al., 1992; Yan et al., 1992; Davies et al., 1993; DiCicco-Bloom et al., 1993; Henderson et al., 1993; Arenas and Persson, 1994) to proliferation of oligodendrocyte precursors (Barres et al., 1994) and axon growth (Zhang et al., 1994).

Our results suggest that microglia are sources of trophic factors known to support development and normal function of CNS cells. Our observations also indicate that microglia are responsive to neurotrophins: brain-derived neurotrophic factor (BDNF) and neurotrophin-3 (NT-3) induce proliferation and phagocytic activity of microglia in vitro.

\section{MATERIALS AND METHODS}

Isolation of microglia. Sprague-Dawley rats were killed by exposure to $\mathrm{CO}_{2}$ on postnatal day 2. Cortices were dissected. Special care was taken to remove all meninges and blood vessels during dissection to minimize contamination by blood monocytes and macrophages. Mixed glial cul- 


\section{NGF \\ CX CX SN SN PC M}

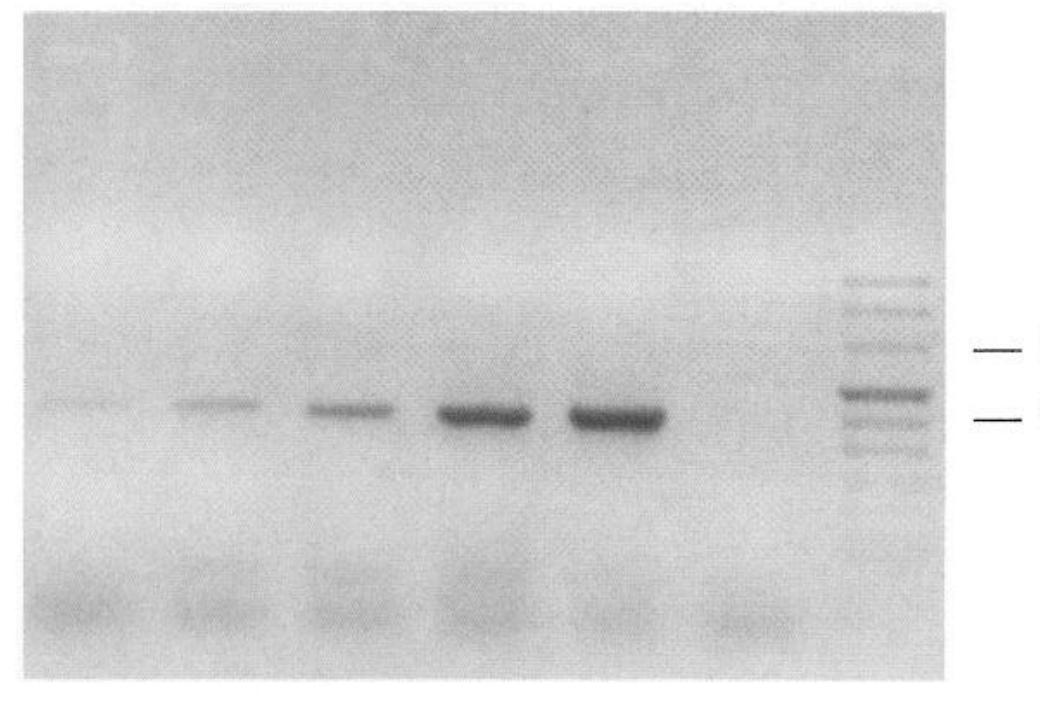

\section{NT-3 \\ NC CX CX SN PC M}

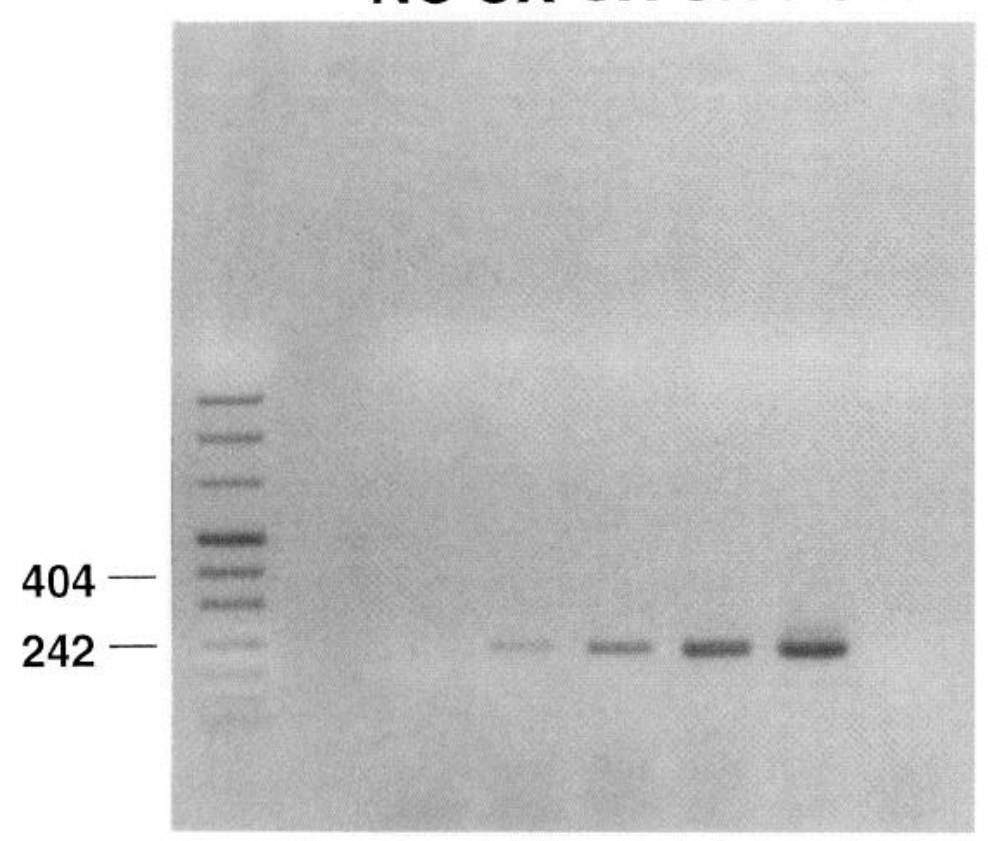

\section{BDNF}

692

404
$\mathrm{M}$ CX

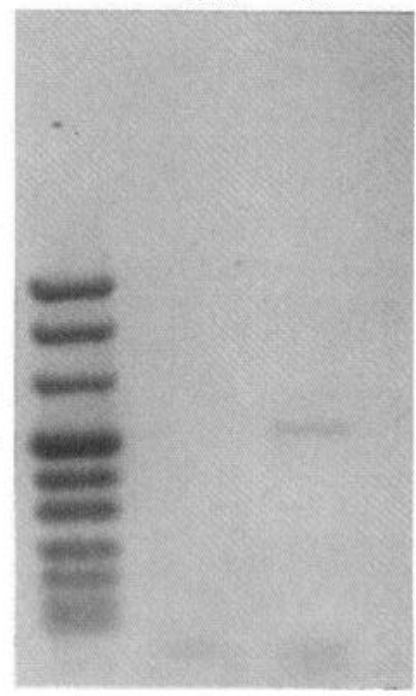

NT-4/5

M CX

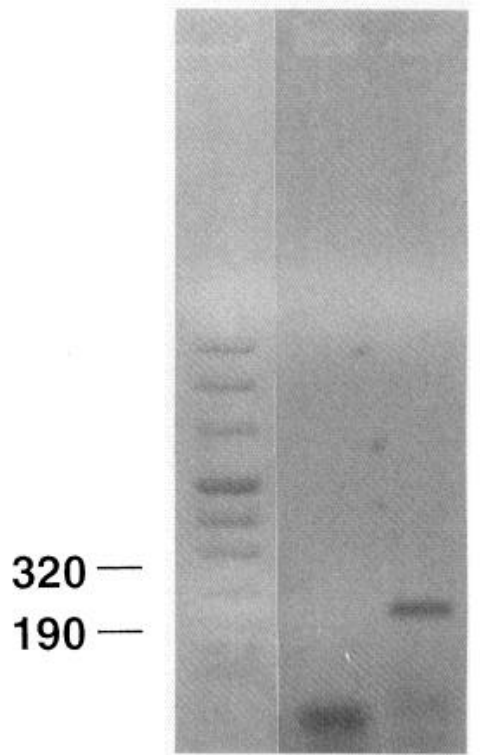

Figure 1. RT-PCR analysis of neurotrophin genes in purified microglia cultures from cortex and substantia nigra. All neurotrophins were expressed by microglia in vitro. The amounts of mRNA used for cortex and substantia nigra were different and, therefore, the PCR analysis is not quantitative. The results of two independent experiments are shown for NGF and NT-3. PCR was performed for 35 cycles. $C X$, Cortex; $S N$, substantia nigra; $P C$, positive control (hippocampal cDNA); $N C$, negative control (mRNA obtained from cortical microglia and treated the same as experimental samples without addition of reverse transcriptase); $M$, mock (sample that did not contain any RNA, treated the same as experimental samples for RT and PCR).

tures were grown by the method of McCarthy and de Vellis (1980) until confluency $(8-10 \mathrm{~d})$. Microglia were isolated and maintained in culture as described previously (Giulian and Baker, 1986).

Cells were grown in $35 \mathrm{~mm}$ dishes in $\mathrm{N} 2$ medium (Bottenstein and Sato, 1979) containing $10 \%$ heat-inactivated fetal bovine serum. In some experiments, microglia were maintained in N2 medium without addition of serum. Microglia/macrophages were identified using the markers OX-42 and ED1 (Dijkstra et al., 1985; Robinson et al., 1986; Graeber et al., 1988). The purity of the cultures was assessed immunocytochemically using astrocyte (glial fibrillary acidic protein, GFAP) and oligodendrocyte (myelin basic protein, MBP) markers. Microglia constituted $98 \%$ of all cells in the culture dish, 2 and $5 \mathrm{~d}$ after plating.

$\left[{ }^{3} H\right]$ thymidine incorporation assays. DNA synthesis was used as a marker for cells in the mitotic cycle (DiCicco-Bloom and Black, 1988). $\left[{ }^{3} \mathrm{H}\right]$ thymidine incorporation studies were carried out as described previously (DiCicco-Bloom et al., 1993). Isolated microglia were cultured in 24-well plates, in N2 medium without addition of serum at a density of 8 $\times 10^{4}$ cells/well. Twenty hours after plating, $\left[{ }^{3} \mathrm{H}\right]$ thymidine $(2 \mu \mathrm{Ci} / \mathrm{ml})$ 

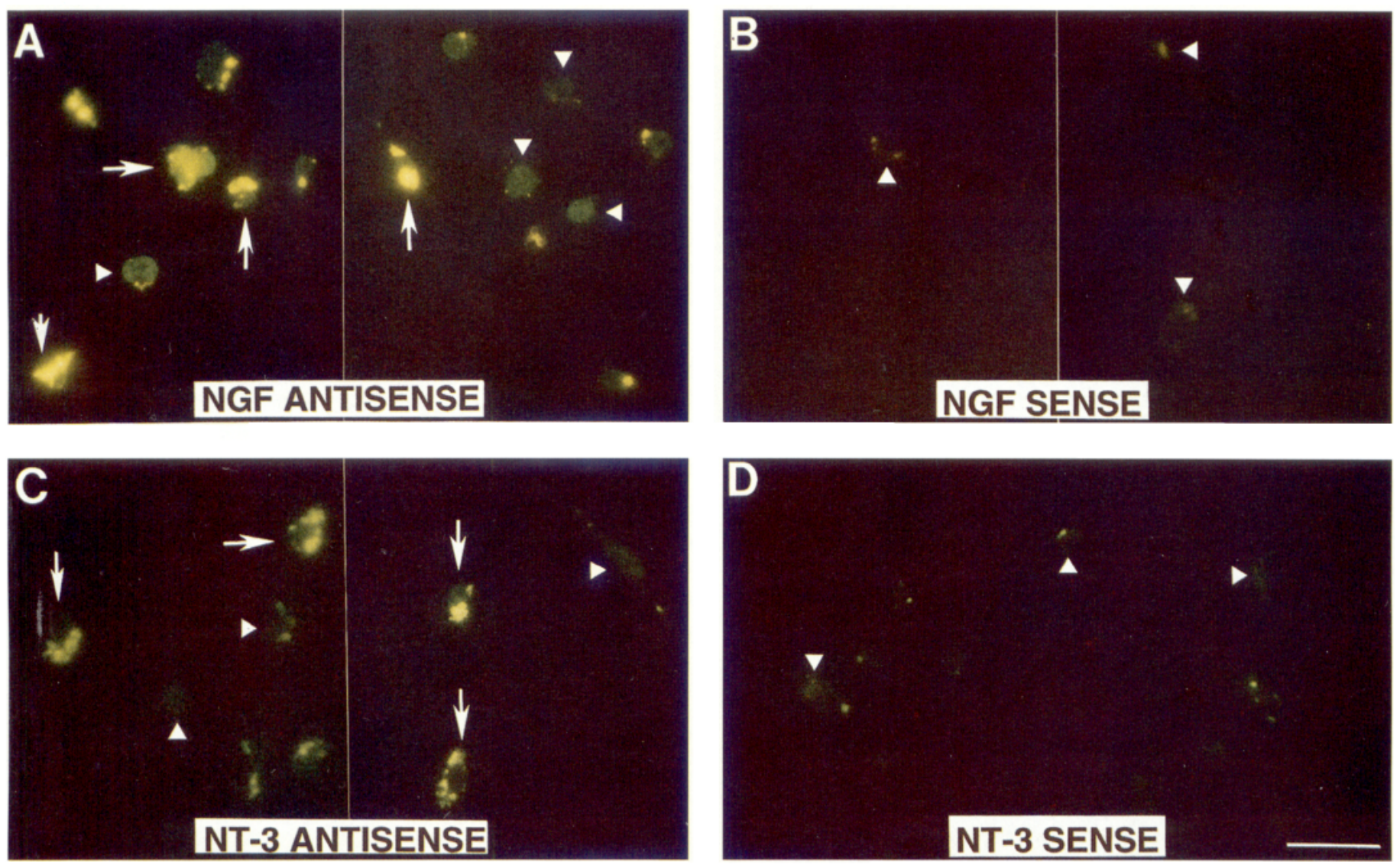

Figure 2. Expression of NGF and NT-3 mRNAs in cortical microglia in vitro. In situ hybridization analysis using digoxygenin-UTP-labeled RNA probes specific for NGF and NT-3. FITC-conjugated anti-digoxygenin antibody was used for the visualization of labeled cells. $A$, Composite picture showing two different fields of the culture dish with cells hybridized to NGF antisense probe. Arrows point to examples of labeled cells. Arrowheads point to cells that showed only background labeling. Only a subpopulation expressed NGF. B, Composite picture showing two different fields of sister cultures labeled with NGF sense probe. Arrowheads point at some cells showing background labeling. $C$, Composite picture showing two different fields of the culture dish with cells hybridized to NT-3 antisense probe. Arrows point to examples of labeled cells. Arrowheads point to some cells exhibiting only background labeling. $D$, Cells hybridized to sense NT-3 probes and showing background labeling in sister cultures. Scale bar, $40 \mu \mathrm{m}$.

was added and the cells were collected $4 \mathrm{hr}$ later with a semiautomatic cell harvester. Incorporation was assayed by scintillation spectroscopy. Four culture wells were used for each group in each experiment.

Morphological analysis of $\left[{ }^{3} \mathrm{H}\right]$ thymidine incorporation was performed by addition of $\left[{ }^{3} \mathrm{H}\right]$ thymidine at $20 \mathrm{hr}$ and fixing the cells at $24 \mathrm{hr}$. Microglia were identified by immunocytochemistry using the OX-42 antibody, as described below. The cultures were then processed for autoradiography as reported previously (DiCicco-Bloom et al., 1988) for visualization of cells exhibiting nuclear incorporation of $\left[{ }^{3} \mathrm{H}\right]$ thymidine. Labeling index was defined as the ratio of cells that incorporated thymidine to total cells present in the dish.

Cell counting. To assess overall microglial numbers, $10^{5}$ cells were plated in $35 \mathrm{~mm}$ dishes in $\mathrm{N} 2$ medium in the presence or absence of serum. Two randomly selected, nonoverlapping $10 \times 0.64 \mathrm{~mm}^{2}$ strips were counted ( $1.2 \%$ of the culture dish area) $24 \mathrm{hr}$ after plating.

Phagocytic activity. Cells were grown in the presence or absence of NT-3 for $24 \mathrm{hr}$. Fluorescent polystyrene microspheres $(0.7 \mu \mathrm{m}$, Covaspheres Particles, FX Green, Duke Scientific, Palo Alto, CA) were then added, and cultures were incubated for an additional $12 \mathrm{hr}$. The cultures were then washed with medium, and the number of spheres/microglia was determined.

$R T$-PCR. Purified microglia maintained $5 \mathrm{~d}$ in culture were rinsed with sterile PBS, pH 7.4. RNA was extracted by the guanidinium-acid phenol procedure (Chomzynski and Sacchi, 1987). The RT-PCR was performed as described previously using primers specific for NGF, BDNF, NT-3, and NT-4 (Elkabes et al., 1995) for 35 cycles.

Preparation of riboprobes. The cDNA probes used in these studies have been described previously (Elkabes et al., 1994). The transcription mixture consisted of $40 \mathrm{~mm}$ Tris buffer, pH $8.0,10 \mathrm{~mm} \mathrm{NaCl}, 10 \mathrm{~mm}$ dithiothreitol, $6 \mathrm{~mm} \mathrm{MgCl} 2,0.5 \mu \mathrm{g}$ of DNA template, $10 \mathrm{U}$ of RNasin, 1
mM each ATP, CTP, GTP, and digoxygenin-UTP, and $20 \mathrm{U}$ of RNA polymerase (SP6 or T7). The mixture was incubated for $2 \mathrm{hr}$ at $37^{\circ} \mathrm{C}$. At the end of the incubation period, the samples were treated with $10 \mathrm{U}$ of DNase for $15 \mathrm{~min}$ at $37^{\circ} \mathrm{C}$ to remove the DNA template. The reaction was stopped by adding $50 \mathrm{~mm}$ EDTA, $\mathrm{pH} 8$. The RNA probe was recovered by ethanol precipitation in the presence of $0.25 \mathrm{M}$ sodium acetate and 10 $\mu \mathrm{g}$ of t-RNA at $-20^{\circ} \mathrm{C}$. Quantitation of the digoxygenin-riboprobe was performed using the Genius 4 and Genius 3 Kits (Boehringer Mannheim, Indianapolis, IN) as described by the manufacturer.

In situ hybridization. Microglia maintained in culture for 1 week were fixed in $4 \%$ paraformaldehyde/PBS for $20 \mathrm{~min}$ at room temperature. They were dehydrated in $30,60,80,95$, and $100 \%$ alcohol and preserved at $-80^{\circ} \mathrm{C}$ until use. On the day of the experiment, cultures were acetylated with $0.1 \mathrm{M}$ triethanol amine, $\mathrm{pH} 8.0,0.9 \% \mathrm{NaCl}$, and $0.25 \%$ acetic anhydride for $10 \mathrm{~min}$ at room temperature, washed in $2 \times \mathrm{SSC}$, and dehydrated in a series of alcohols. One hundred microliters of hybridization mixture consisting of $50 \%$ deionized formamide, $0.75 \mathrm{M}$ $\mathrm{NaCl}, 0.1 \mathrm{~m}$ Tris buffer, pH 7.8, 5 m $\mathrm{m}$ EDTA, 2\% SDS, 0.1\% Ficoll, $0.1 \%$ polyvinylpyrrolidone, $0.1 \%$ bovine serum albumin (BSA), $50 \mathrm{~mm}$ dithiothreitol, $25 \mu \mathrm{g} / \mathrm{ml}$ tRNA, and $50 \mu \mathrm{g} / \mathrm{ml}$ salmon sperm DNA, and digoxygenin-labeled sense or antisense probe $(2 \mu \mathrm{g} / \mathrm{ml})$ was applied to each culture. Hybridization was performed at $45^{\circ} \mathrm{C}$ for $24 \mathrm{hr}$ in a humidified box. After hybridization, the cultures were washed in $4 \times$ SSC and treated with RNase A $(20 \mu \mathrm{g} / \mathrm{ml})$ in $0.5 \mathrm{M} \mathrm{NaCl}, 10 \mathrm{~mm}$ Tris buffer, $\mathrm{pH} 7.6$, for $30 \mathrm{~min}$. The cultures were then washed with $2 \times \mathrm{SSC}$ for $2 \mathrm{hr}$ at room temperature followed by $0.1 \times \mathrm{SSC}$ for $1 \mathrm{hr}$ at $55^{\circ} \mathrm{C}$. Cultures were then incubated in PBS containing $50 \mu \mathrm{g} / \mathrm{ml}$ antidigoxygenin antibody conjugated to fluorescein, for $1 \mathrm{hr}$, at room temperature. Excess antibody was washed extensively with PBS, and 

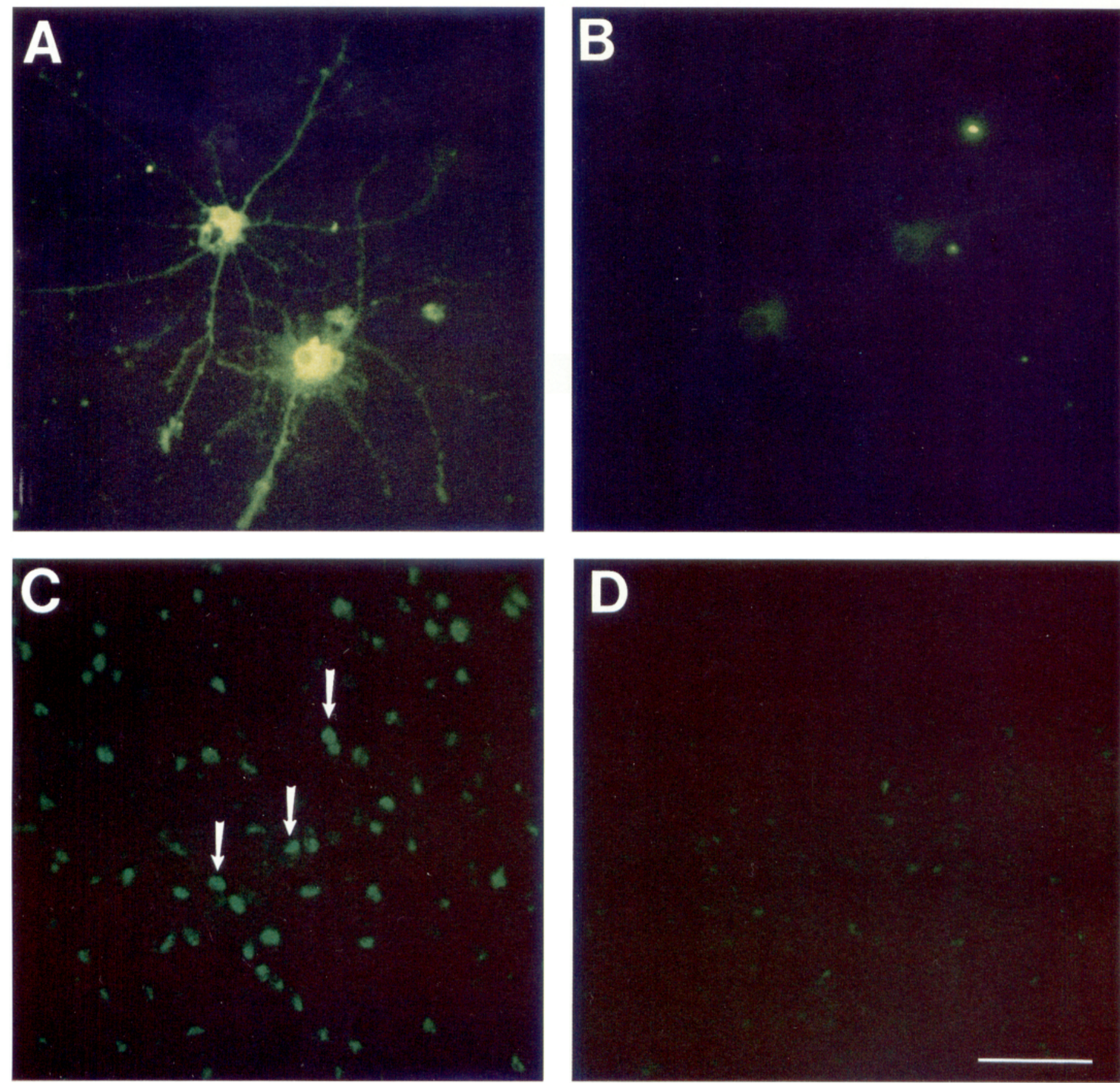

Figure 3. Specificity of the NT-3 antibody. Fluorescence micrographs showing $(A)$ cells labeled with anti-NT-3 antibody in vitro, $(B)$ cells in sister cultures, labeled with anti-NT-3 antibody preadsorbed with NT-3, and $(C)$ an adult brain section through the cortex labeled with anti-NT-3 antibody. Arrows point to some cells exhibiting NT-3 immunoreactivity. $D$, A section adjacent to that shown in $C$ and labeled with anti-NT-3 antibody preadsorbed with NT-3. Note that the immunoreactivity was significantly reduced by this treatment. Scale bar, $50 \mu \mathrm{m}$.

cultures were coverslipped in Vectashield (Vector Laboratories, Burlingame, CA).

Antibodies. Anti-NT-3 polyclonal antibody was purchased from Chemicon (Temecula, CA). The antibody, characterized by the manufacturer, was specific for NT-3 and did not cross-react with BDNF or NGF. To determine further the suitability of this antibody for immunocytochemical studies, we preadsorbed the antibody $(2 \mu \mathrm{g} / \mathrm{ml})$ with NT-3, BDNF, or NGF at a concentration of $2 \mu \mathrm{g} / \mathrm{ml}$. NT-3 completely adsorbed the immunoreactivity (Fig. 3), whereas BDNF and NGF were ineffective (data not shown). In addition, studies on brain sections (see below) indicated that these antibodies labeled cells in regions that have been described previously to express the NT-3 gene such as the cingu- late cortex and the hippocampus (Friedman et al., 1991) (data not shown).

OX-42 and ED1 were monoclonal antibodies purchased from Serotec (Oxford, UK).

Immunocytochemistry. Animals were perfused with $0.9 \% \mathrm{NaCl}$ followed by $4 \%$ paraformaldehyde $/ 15 \%$ picric acid. Brains were dissected, maintained in the same solution for $1 \mathrm{hr}$ at $4^{\circ} \mathrm{C}$, cyroprotected in $15 \%$ sucrose, and frozen in crushed dry ice. Five micrometer sections, taken on a cryostat, were mounted on poly-L-lysine-coated slides. Sections were first treated with $20 \%$ horse serum/PBS for $1 \mathrm{hr}$ at room temperature. They were then incubated in a mixture of anti-NT-3 antibody $(2 \mu \mathrm{g} / \mathrm{ml})$ and OX-42 (1:100, $\mathrm{v} / \mathrm{v})$ in PBS for $48 \mathrm{hr}$ at $4^{\circ} \mathrm{C}$. The rest of the procedure was performed at room temperature. 

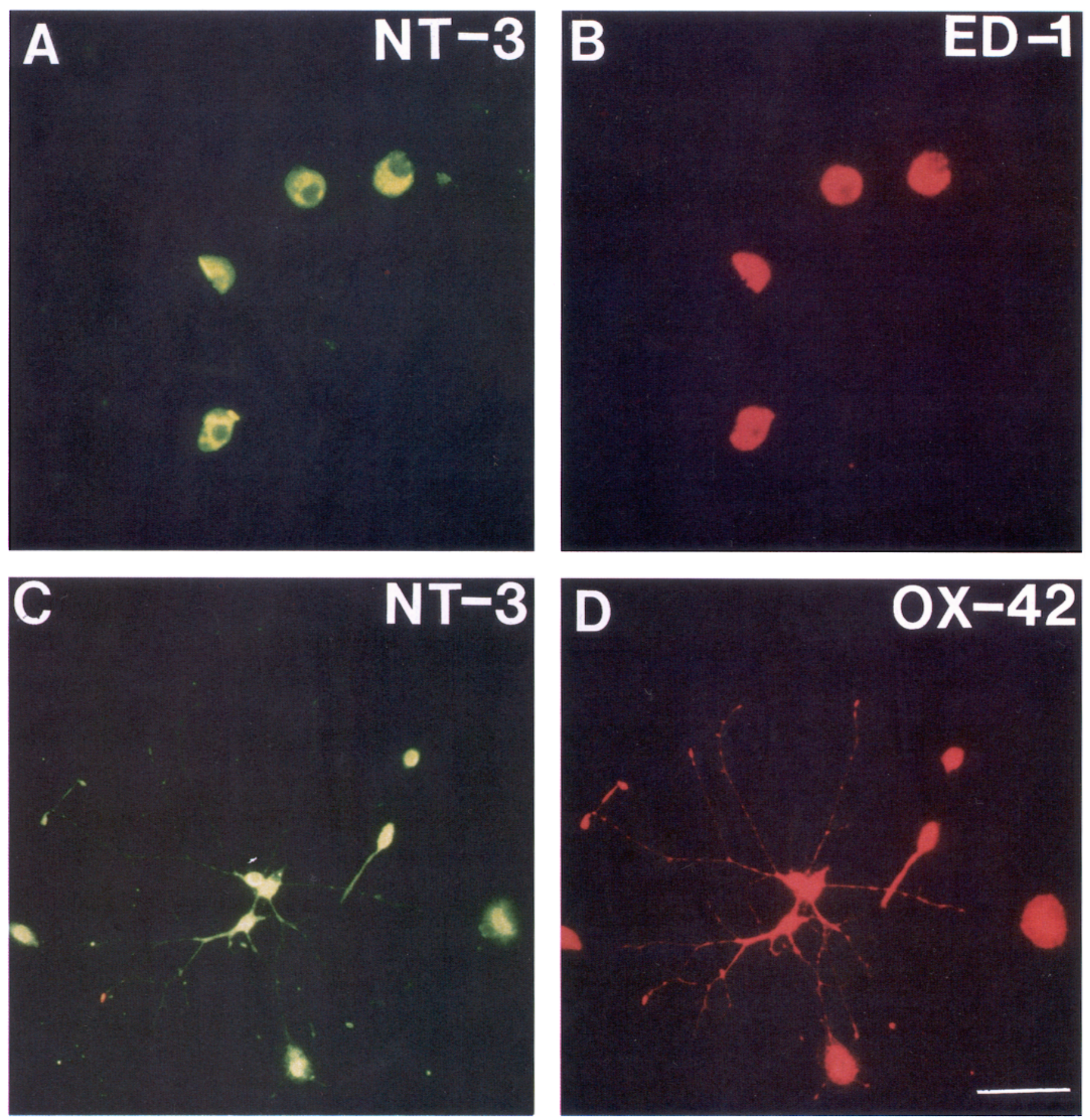

Figure 4. Colocalization of OX-42 and ED1 with NT-3 immunoreactivity in cortical microglia in vitro. Cultures were double-labeled with anti-NT-3 antibody and OX-42 or ED1 antibody as described in Materials and Methods. $A$, Cells with amoeboid morphology exhibiting NT-3-like immunoreactivity. $B$, The cells presented in $A$ showed ED1 immunopositivity. $C$, Cells with diverse morphology showing NT-3-like immunoreactivity. $D$, The group of cells presented in $C$ was also labeled with OX-42 antibody. Scale bar, $40 \mu \mathrm{m}$.

Sections were rinsed three times in PBS for 15 min and were incubated with a mixture of fluorescein isothiocyanate (FITC)-conjugated anti-rabbit IgG $(1: 100, \mathrm{v} / \mathrm{v})$ and biotinylated-anti-mouse $\operatorname{IgG}(1: 500, \mathrm{v} / \mathrm{v})$ in BSA/PBS (1 mg/ $\mathrm{ml}$ ) for $1 \mathrm{hr}$. They were then incubated in Texas Red-conjugated avidin (40 $\mu \mathrm{g} / \mathrm{ml}$ ) in $10 \mathrm{mM}$ HEPES for $30 \mathrm{~min}$, rinsed, treated with chloroform/ethanol $(1: 1, \mathrm{v} / \mathrm{v})$ for $1 \mathrm{hr}$, and coverslipped in Vectashield.

The procedure used for tissue culture was similar to that described for sections. In some experiments, the avidin-biotin/3,3' diaminobenzidine technique was used for visualization of OX42 -immunoreactive cells. Fixed cultures were incubated with OX-42 antibody. Cells were then exposed to anti-mouse IgG (1:500) and avidin-biotin complex reagents (Vectastain ABC kit, Vector). Staining was made visible by 3,3'-diaminobenzidine reaction product.

\section{RESULTS}

\section{Expression of neurotrophin genes by purified microglia} in culture

To investigate whether microglia elaborate neurotrophins in vitro, we performed reverse transcription (RT)-PCR analysis 

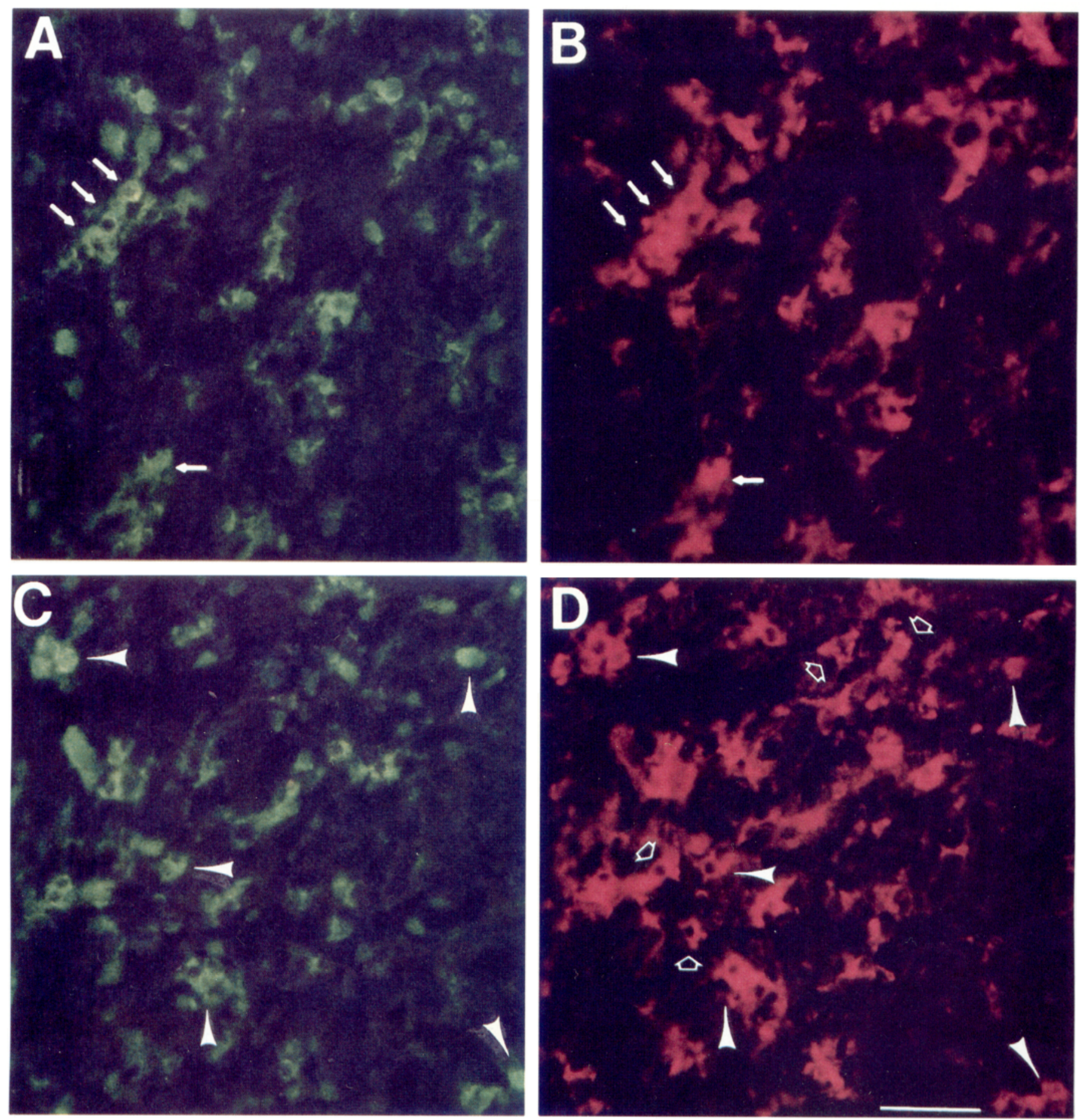

Figure 5. Fluorescence micrographs showing localization of NT-3 and OX-42 immunoreactivity in brain sections from a rat on postnatal day $10 . A$ and $B$ show cells (small arrows) along blood vessels, potentially perivascular cells, double-labeled with anti-NT-3 $(A)$ and OX-42 $(B)$ antibodies. $C$ and $D$ show a group of cells in cortex labeled with anti-NT-3 $(C)$ and OX-42 $(D)$ antibodies. Arrowheads point at some double-labeled cells. Open arrows point at some OX-42-positive cells that did not exhibit NT-3-like immunoreactivity. Only a subpopulation was double-labeled. Scale bar, $40 \mu \mathrm{m}$.

for the NGF, BDNF, NT-3, and NT-4/5 genes using primers specific for each factor (Elkabes et al., 1995). All neurotrophins were expressed by microglia in vitro. BDNF cDNA levels appeared to be lower than those of the other neurotrophins. Expression of neurotrophins was not limited to cortical microglia; NGF and NT-3 were also expressed by substantia nigra microglia (Fig. 1).
To assess whether all microglia express neurotrophin genes, and to ensure further that the signal amplified by PCR was indeed associated with microglia rather than contaminating cells $(<2 \%)$, we performed in situ hybridization analysis. When cultures were hybridized with antisense RNA probes specific for NGF and NT-3, a strong signal over background in a subpopulation of cells with microglial morphology was obtained (Fig. 2). Fewer micro- 

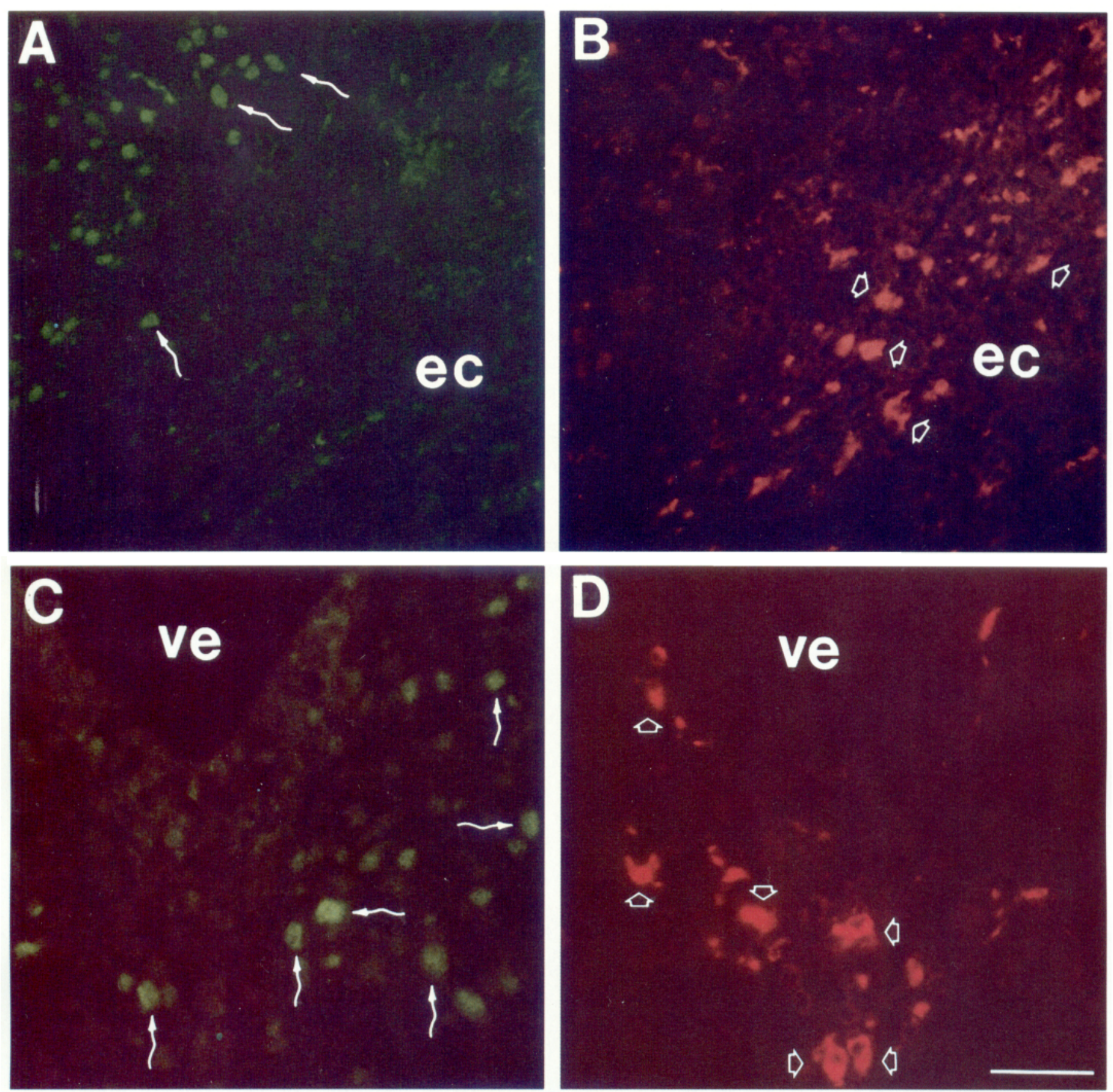

Figure 6. Fluorescence micrographs showing brain regions rich in OX-42-immunoreactive cells that do not express NT-3. $A$ and $B$ show a section through the external capsule (ec) double-labeled with anti-NT-3 $(A)$ and OX-42 $(B)$ antibodies. $C$ and $D$ show a section through the third ventricle (ve) double-labeled with anti-NT-3 $(C)$ and OX-42 $(D)$ antibodies. Note that OX-42-immunoreactive cells were abundant in both regions but did not exhibit NT-3 immunoreactivity $(o p e n$ arrows). Undulating arrows point at some cells in adjacent regions that were positive for NT-3 and negative for OX-42 immunoreactivity. Scale bar, $40 \mu \mathrm{m}$.

glia were labeled with the NGF probe ( $30 \%$ of total cells) compared with NT-3 (60-70\% of total cells), although the signal obtained with the latter was weaker. In agreement with our RT-PCR studies, a few cells were weakly labeled with the BDNFspecific probe (data not shown). Neurotrophin genes were not restricted to microglia of any single morphological class; ramified, amoeboid, and rod-shaped cells expressed NGF and NT-3.

\section{Elaboration of NT-3 protein by microglia in vitro}

To determine whether microglia synthesize neurotrophin protein, we performed immunocytochemistry. We focused primar- ily on NT-3, because antisera specific for NGF and NT-4 for immunocytochemistry are not available. The anti-NT-3 antibody appeared to be specific for this trophin: preadsorption with NT-3 (Fig. 3) but not BDNF or NGF (data not shown) significantly diminished the signal.

To determine whether NT-3 is colocalized with markers of microglia and brain macrophages, we double-labeled sister cultures with anti-NT-3, and OX-42 or ED1. In agreement with our in situ hybridization studies, NT-3 was expressed by microglial subpopulations. Cells immunopositive for OX-42 and ED1, exhibiting amoeboid or 

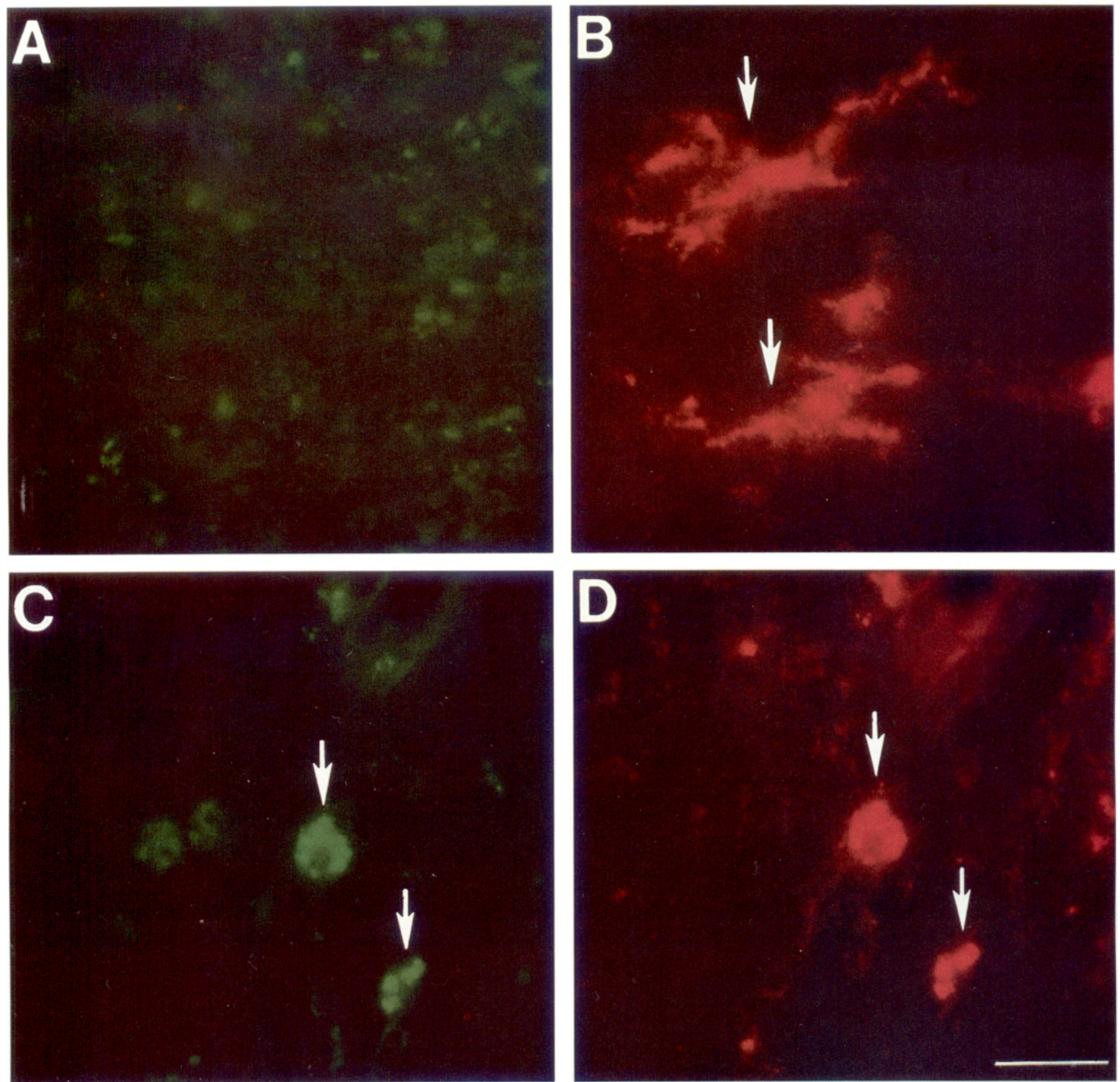

Figure 7. NT-3 immunoreactivity in adult microglia. $A$ and $B$ show a section through the cortex double-labeled with anti-NT-3 $(A)$ and OX-42 $(B)$ antibodies. Ramified microglia $(B$, arrows) did not exhibit NT-3 immunoreactivity $(A)$. $C$ and $D$ show cells along blood vessels that were double-labeled with anti-NT-3 $(C)$ and OX-42 $(D)$ antibodies. Double-labeled cells along blood vessels were seen only occasionally. Scale bar, $35 \mu \mathrm{m}$.

rod-shape morphology, as well as microglia with long, branched processes bearing fine protrusions, were labeled with the anti-NT-3 antiserum (Figs. 3, 4). NT-3-immunoreactive cells constituted $80 \%$ of the total OX-42 or ED-1-positive cells.

\section{Expression of NT-3 by microglia in vivo}

To determine whether microglia elaborate neurotrophins in vivo, we performed double-labeling with anti-NT-3 and OX-42 antibodies in sections of postnatal day 10 and 90 rat brain. We studied both the developing and the adult brain, because microglia in the immature and mature brain exhibit different properties. In the developing brain, microglia are phagocytic cells with amoeboid morphology, whereas in the adult brain, they are ramified resting cells. We used NT-3 as the prototypical neurotrophin, because in vitro studies suggested that a large microglial subpopulation elaborates the trophin.

On postnatal day 10, only a subpopulation of OX-42-positive cells exhibited NT-3 immunoreactivity in the cortex, globus pallidus, and the medulla (Fig. 5). In contrast, no OX-42-positive cells exhibited NT-3 reactivity in the external capsule, ventricular ependymal lining, meninges, and choroid plexus (Fig. 6). In the ependymal lining and choroid plexus, OX-42-labeled cells were 
Figure 8. Effects of BDNF and NT-3 on $\left[{ }^{3} \mathrm{H}\right]$ thymidine incorporation in cortical microglia in culture. Microglia were cultured in control medium or in medium containing 3 and $30 \mathrm{ng} / \mathrm{ml} \mathrm{BDNF}$ or NT-3. The data are derived from three $(B D N F)$ or four $(N T-3)$ separate experiments consisting of four dishes per group. Values represent mean percent of control \pm SEM. Significantly different from control: ${ }^{*} p<0.0005$, ${ }^{* *} p<0.0001$ for BDNF; ${ }^{*} p<0.016,{ }^{* *} p<$ 0.0014 for NT-3 by ANOVA (Scheffe's test).
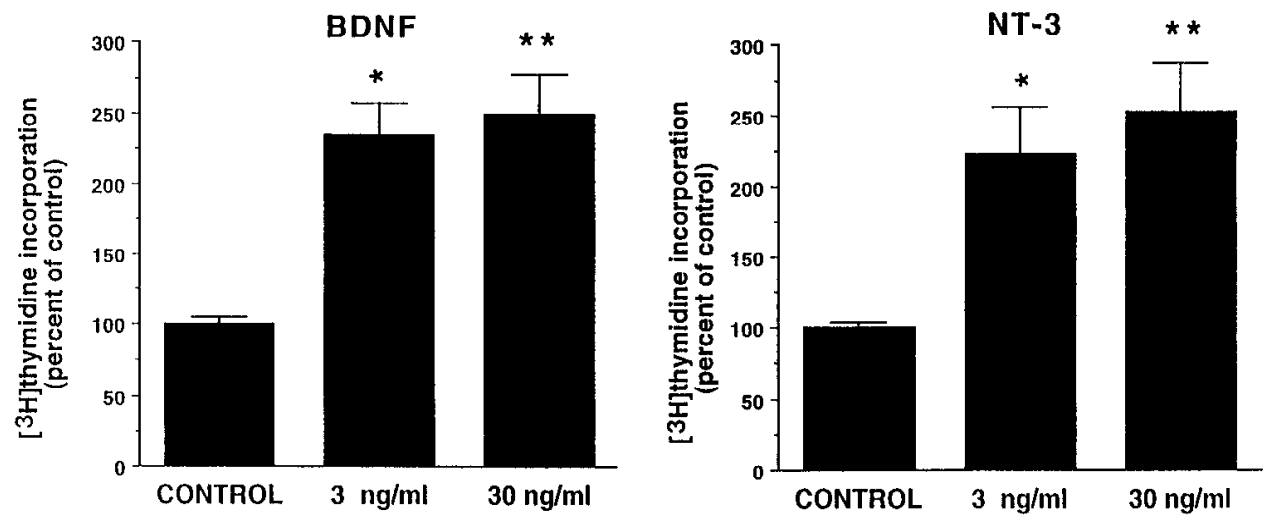

immediately adjacent to NT-3-immunopositive nonmicroglial cells. In addition to microglia within the brain parenchyma, OX42-immunoreactive cells along blood vessels, potentially perivascular cells (Hickey et al., 1988; Graeber et al., 1989), also exhibited NT-3 immunoreactivity (Fig. 5A, B).

In contrast, in the adult, $\mathrm{OX}-42$-immunoreactive ramified cells were not NT-3-positive, suggesting that microglial NT-3 expression is downregulated with maturation and the appearance of ramified resting microglia (Fig. $7 A, B$ ). Occasionally, OX-42positive round cells along blood vessels were labeled with the anti-NT-3 antibody (Fig. 7C,D).

\section{NT-3 and BDNF stimulate microglial proliferation in vitro}

One of the responses of resting microglia to brain inflammation or injury is proliferation. In light of endogenous neurotrophin expression, we examined the potential role of the factors in regulating microglial cell division. As a first step, the effects of the neurotrophins on incorporation of $\left[{ }^{3} \mathrm{H}\right]$ thymidine, a marker for DNA synthesis, were assessed after culture for $24 \mathrm{hr}$ in serum-free media. BDNF and NT-3 increased incorporation 2.5-fold (Fig. 8), comparable with that elicited by serum (fourfold increase). In contrast, NGF was without effect at all doses examined (data not shown).

Although the factors increased DNA synthesis, cell number at $24 \mathrm{hr}$ did not increase (Fig. 9A), suggesting that serum-free medium was inadequate for sustained proliferation. Consequently, neurotrophin effects were examined in an enriched culture environment, $10 \%$ serum. Exposure to NT-3 yielded a twofold increase in total cell number compared with that initially plated ( 0 time), indicating that the factor stimulated proliferation (Fig. 9B). In contrast, NGF and BDNF were ineffective (data not shown). Recent studies have indicated that two distinct mechanisms underly enhanced proliferation (DiCicco-Bloom et al., 1988, 1993). Factors may directly stimulate mitogenesis, increasing the proportion of cells incorporating $\left[{ }^{3} \mathrm{H}\right]$ thymidine (labeling index), or may promote survival, without changing the labeling index. To define NT-3 effects on microglial proliferation, cultures were pulsed with $\left[{ }^{3} \mathrm{H}\right]$ thymidine for $4 \mathrm{hr}$ and processed for combined autoradiography and OX-42 immunocytochemistry. Autoradiographic silver grains were specifically localized to nuclei of OX-42-positive cells (Fig. 10), indicating that microglia comprised the mitotic population. In control cultures, in which cell number did not change (Fig. 9B), <3\% of microglia were mitotic (Fig. 9C), indicating that there was little cell production or death during the first $24 \mathrm{hr}$ of incubation. In contrast, after NT-3 exposure, the labeling index increased fivefold, indicating that the factor stimulated mitogenesis. Indeed, on average, every microglial cell divided once to produce a doubling in cell number.

In addition to stimulating mitogenesis, NT-3 may also provide a trophic signal. When microglia were incubated for $72 \mathrm{hr}, 50 \%$ of the cells initially plated were lost (Fig. 9B). In the presence of NT-3, however, cell loss was attenuated: there were fourfold more cells after trophin exposure, and microglial number exceeded that of 0 time. In sum, NT-3 induces microglial proliferation through enhanced cell division and survival.

\section{NT-3 induces morphological changes and phagocytic activity in vitro}

Induction of microglial proliferation is one of the steps associated with cellular activation after inflammation and injury. Activated microglia also undergo morphological changes and exhibit increased phagocytic activity. Exposure of cells to NT-3 for $72 \mathrm{hr}$ elicited a markedly different cellular morphology: microglia treated with the trophin were large and flat, and had extended processes, whereas control cells were small and round, exhibiting no processes (Fig. 11).

To determine whether NT-3 influenced phagocytic activity, we exposed cells to the trophin for $72 \mathrm{hr}$ before presentation of fluorescent-labeled microspheres. Activated microglia that exhibit increased phagocytic activity engulf a larger number of microspheres (Giulian and Ingeman, 1988). NT-3 elicited a fivefold increase in the number of cells that were heavily labeled with beads ( $>30$ beads/cell) (Figs. 12, 13), indicating that the trophin promoted phagocytic activity.

\section{DISCUSSION}

Microglia have been implicated in degencrative disorders of the nervous system, in autoimmune diseases, and in brain injury, primarily as producers of cytotoxic agents (McGeer et al., 1987; Giulian et al., 1990, 1993; Vaca and Wendt, 1992). However, little is known about potential trophic roles of microglia. In one instance, microglia may foster brain development by clearing cellular debris during neuronal death and synaptic elimination and by elaborating trophic factors that support neurons and glia. For example, cytokines released by microglia induce proliferation of astrocytes (Giulian et al., 1988; Hetier et al., 1988; Righi et al., 1989; Selmaj et al., 1990) and regulate glial function (Lindholm et al., 1988). Another family of trophic factors central to multiple developmental processes is the neurotrophins. Our observations suggest that microglia normally elaborate neurotrophins, which regulate microglial proliferation. 
A

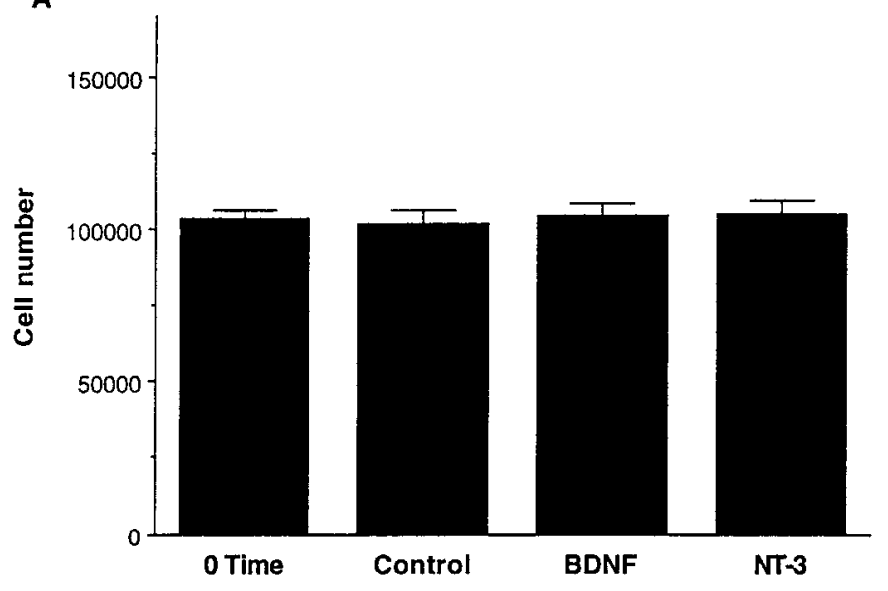

B
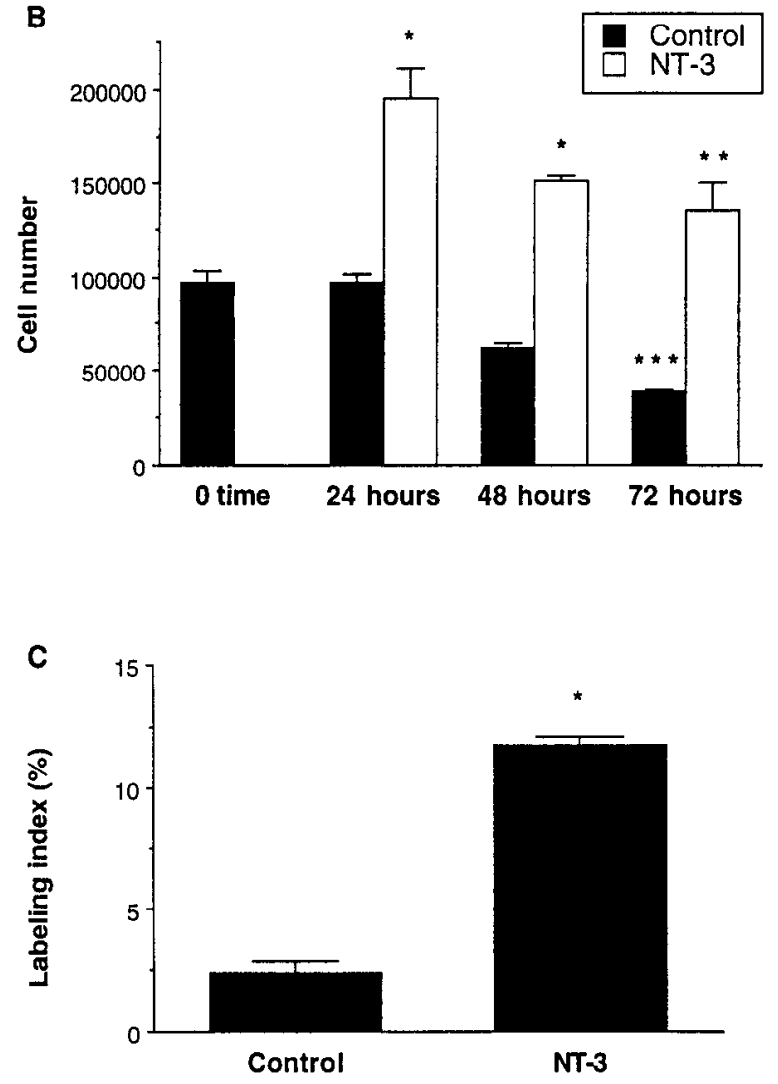

Figure 9. Effects of neurotrophins on proliferation of purified microglia maintained in serum-free and serum-containing medium. Sister cultures were prepared in $35 \mathrm{~mm}$ dishes, and cell number was assessed $3 \mathrm{hr}$ ( 0 time) and $24-72 \mathrm{hr}$ after plating as described in Materials and Methods. $A$, Neurotrophins did not alter total cell number in cultures grown in serumfree medium. $B$, NT-3 induced proliferation of microglia in the presence of serum. Values are the mean of four dishes \pm SEM in a representative experiment. The experiment was repeated five times. Although some variability was noted potentially attributable to changes in the NT-3responsive population, the factor always elicited significant increases in proliferation. *, Significantly different from 0 time and all control groups $(p<0.02) ; * *$, significantly different from 0 time, all control groups, and NT-3 at 24 hr $(p<0.01) ;{ }^{* * *}$, significantly different from 0 time $(p<$ 0.05 ) by ANOVA (Scheffe's test). $C$, Labeling index was defined as the ratio of mitotic microglia visualized by autoradiography to total cells. *, Significantly different from control $(p<0.05)$ by Student's $t$ test.
Heterogeneity of neurotrophin expression by microglia Microglia expressed NGF, BDNF, NT-3, and NT-4 in vitro as indicated by RT-PCR and in situ hybridization. However, expression of NGF and NT-3 was limited to a subpopulation, suggesting cellular heterogeneity. Our in vivo investigations substantiated these results: NT-3 immunoreactivity was associated with only a subset of microglia within a particular brain region. Heterogeneity of microglial neurotrophin expression suggests that different subpopulations subserve different functions. Some microglia may act as antigen-presenting or phagocytic cells, others may produce cytotoxic agents under pathological conditions, and yet another group may elaborate trophic factors during normal development. The regulation of microglial function in the brain may be the consequence of cross-talk among the different subpopulations. Heterogeneity of microglia with regard to major histocompatibility complex class I and II antigen expression has been reported (Streit et al., 1989). In addition, it has been shown that microglial subpopulations in the facial nucleus express distinct antigens after facial nerve injury (Streit and Gracber, 1993). Moreover, microglia respond in diverse manners to different brain reactions (Flaris et al., 1993). These results and our observations imply functional and phenotypic heterogeneity among microglia.

\section{Regional specificity of neurotrophin expression by microglia}

The restricted distribution of anti-NT-3 and OX-42 doublelabeled cells in vivo indicated region-specific expression. Elaboration of NT-3 by microglia was confined to particular regions, suggesting that microglia in different brain regions exhibit different properties. Although multiple mechanisms may be responsible, the microenvironment may provide cues influencing microglial phenotype and modulating expression of trophins and transmitters. Influence of the microenvironment on the distribution, density, and morphology of microglia in the normal mouse brain has been reported (Lawson et al., 1990). In some regions, neurotrophin expression may occur normally, whereas in others it may be triggered by changes in the surrounding cells after illness or injury. These results suggest that microglia potentially serve different functions in different brain regions.

\section{Potential role of microglial neurotrophin expression}

The expression of NT-3 by microglia in the postnatal day 10 brain in vivo suggests that the cells elaborate trophins as part of development. Various reports indicate that microglia or microglia-conditioned media promote neuronal survival and stimulate myelin synthesis in vitro (Nagata et al., 1993; Hamilton and Leonard, 1994). Neurotrophin effects on the survival of multiple neuronal subtypes have been reported (Levi-Montalcini and Angeletti, 1968; Thoenen and Barde, 1980; Hamburger et al., 1981; Collazo et al., 1992; Yan et al., 1992; Davies et al., 1993; DiCiccoBloom et al., 1993; Henderson et al., 1993; Arenas and Persson, 1994). Recent studies also suggest neurotrophin-dependent changes in myelin protein elaboration (Lee et al., 1994). Consequently, trophins expressed and released by microglia may regulate neuronal and oligodendrocyte survival and function during development.

Moreover, our results indicate that NT-3 promotes microglial proliferation and phagocytosis. Enhancement of phagocytic cell production and phagocytosis may be essential during development, when natural cell death and synaptic elimination occurs. The absence of NT-3 immunoreactivity in ramified microglia of the adult brain suggests that expression of the 

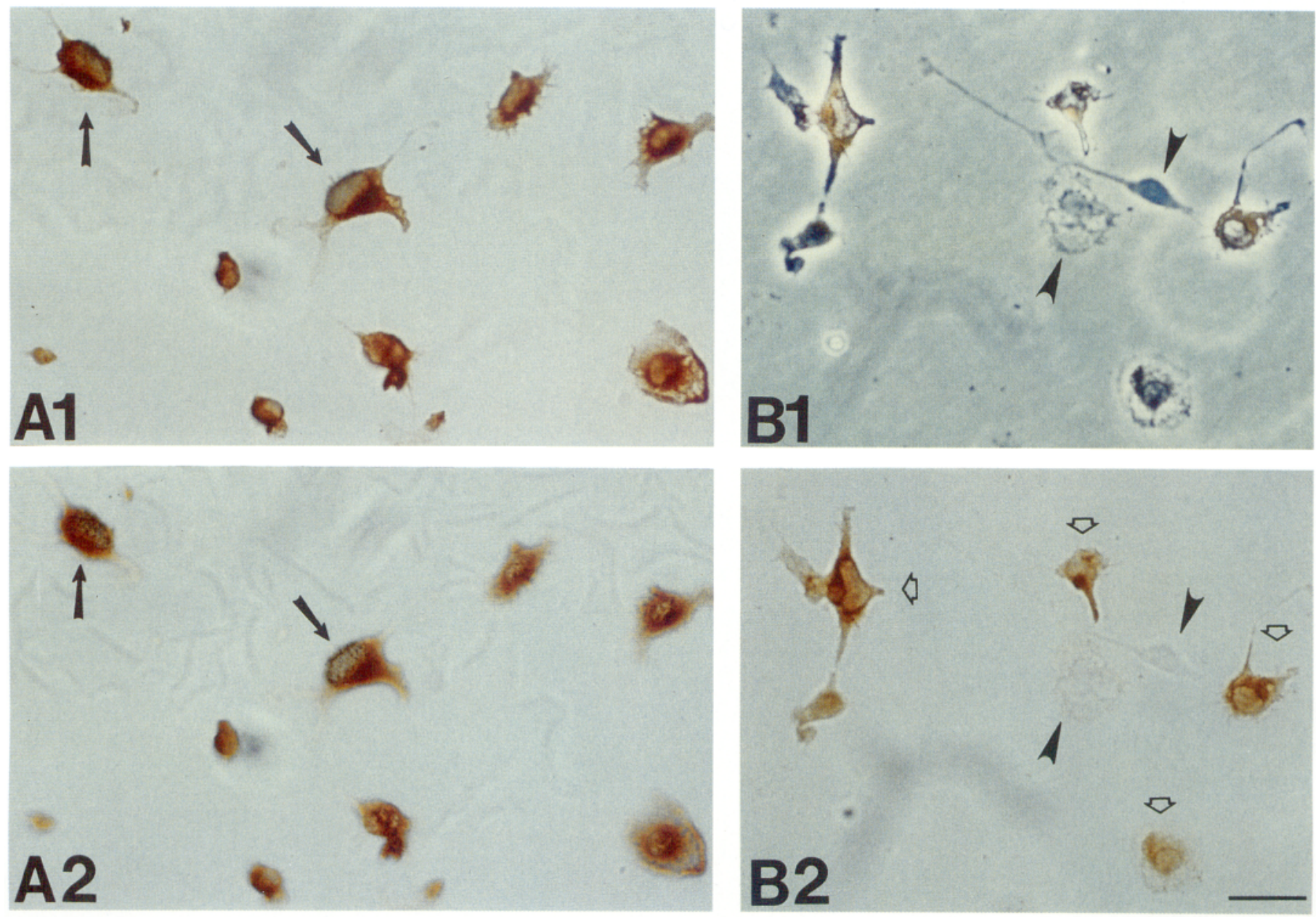

Figure 10. OX-42-positive microglia incorporate $\left[{ }^{3} \mathrm{H}\right]$ thymidine and divide in culture. $A 1$, Bright-field photomicrograph of cells exhibiting OX-42 immunoreactivity. Arrows point to cells that were OX-42-positive and exhibited silver grain-labeled nuclei as shown in $A 2$. B1, Phase photomicrograph of microglia in culture. Arrowheads point to two contaminating cells that did not exhibit OX-42 immunoreactivity as shown in B2, indicating selectivity of OX-42 staining for microglia/macrophages. Open arrows point at examples of OX-42-positive cells. Scale bar, $40 \mu \mathrm{m}$.

trophin is downregulated when amoeboid microglia, phagocytic cells present in the developing brain, change into the resting adult form. It is possible that adult microglia express trophins only when pathological stimuli promote cellular acti- vation. Trophins elaborated by activated cells may mediate the cross-talk between immune system and brain, or they may protect cells from toxic effects induced by other microglial subsets.
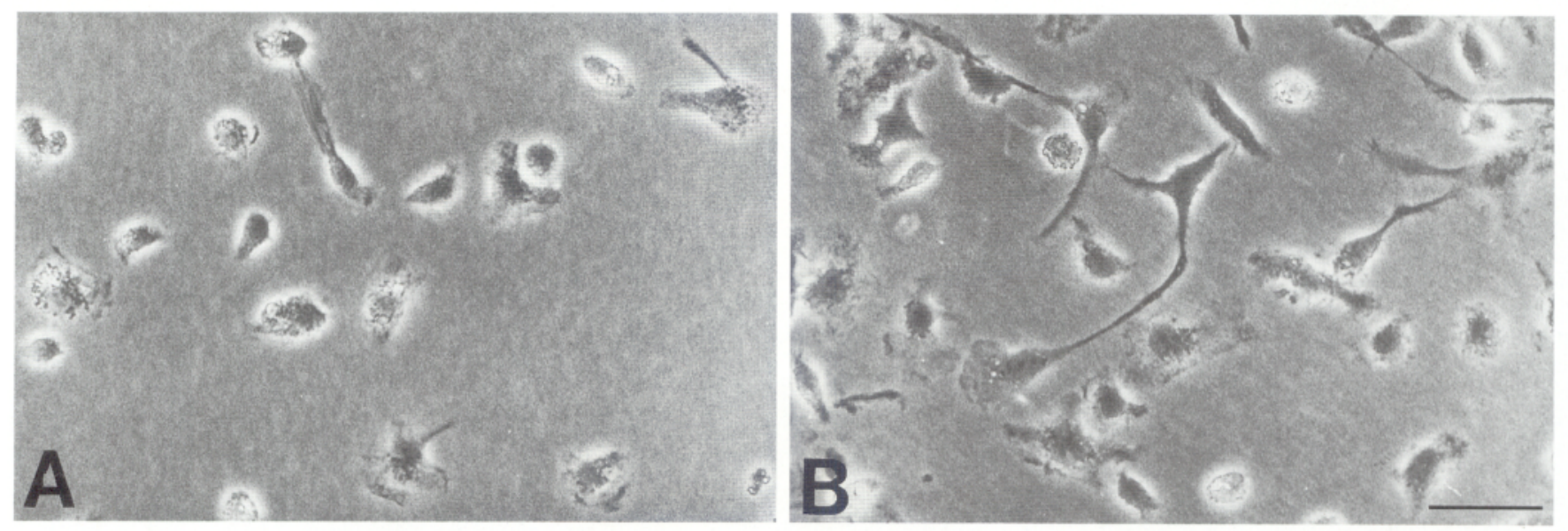

Figure 11. Effects of NT-3 on microglial morphology. Microglia were exposed to NT-3 for 72 hr. Cells maintained in control medium were small and round $(A)$, whereas cells exposed to NT-3 were large, flat, and had extended processes $(B)$. Scale bar, $40 \mu \mathrm{m}$. 

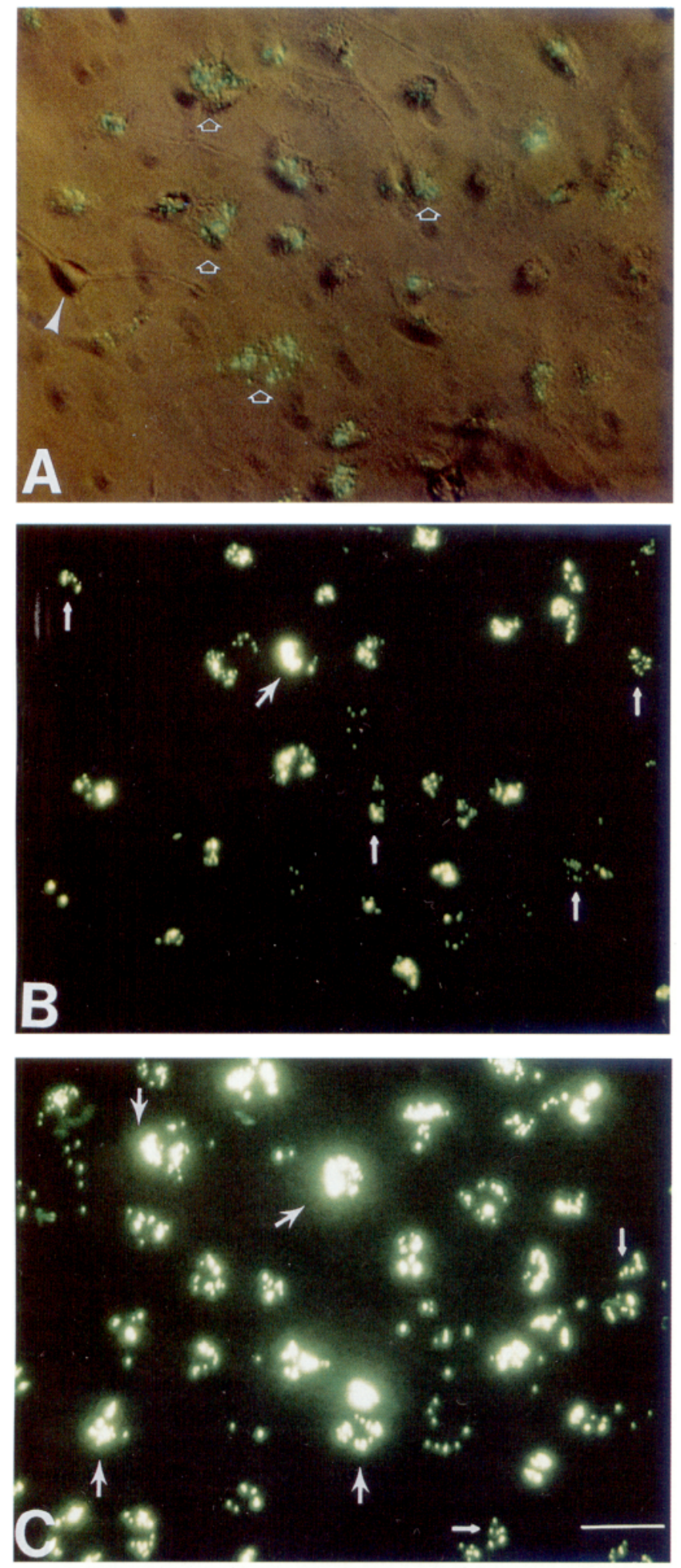

Figure 12. Effects of NT-3 on phagocytic activity of microglia. $A$, Brightfield photomicrograph showing cells that engulfed fluorescent microspheres (arrows). Arrowhead points to a cell that did not engulf microspheres, showing the specificity of the approach for detection of phagocytic microglia. $B$, Fluorescent photomicrograph of a control culture showing cells that engulfed microspheres. $C$, In the presence of NT-3, the number of microspheres per cell increased markedly. In $B$ and $C$, small arrows point to examples of cells with low phagocytic activity $(<30$ spheres/cell) and large arrows point to examples of cells that exhibited high phagocytic activity ( $>30$ spheres/cell). Scale bar, $60 \mu \mathrm{m}$.

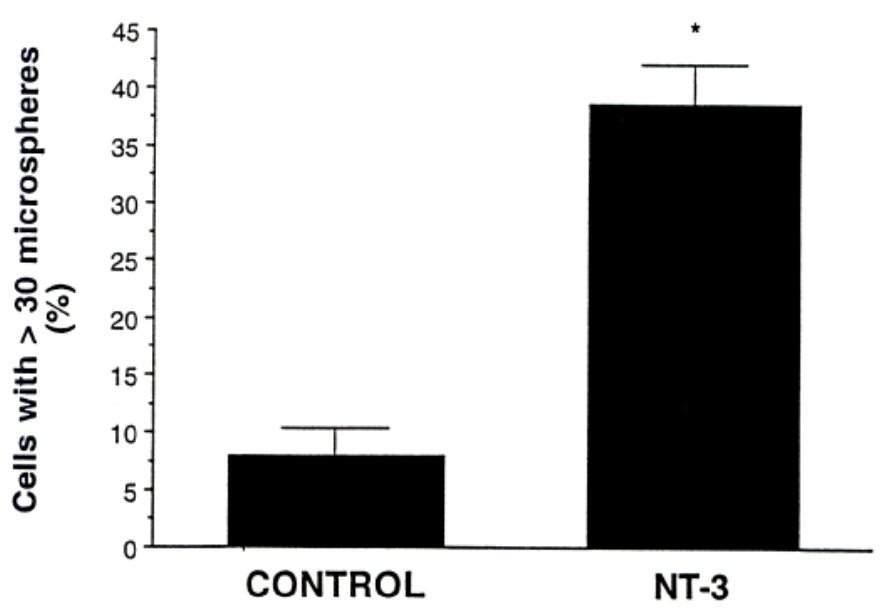

Figure 13. Effects of NT-3 on the incorporation of fluorescent microspheres into microglia. The number of microspheres engulfed by cells shown in Figure 12 was counted. The ratio of cells that engulfed spheres over mean control levels ( 30 beads/cell) to total cells with microspheres is represented. *, Significantly different from control $(p<0.002)$ by Student's $t$ test.

\section{Effects of neurotrophins on microglia}

Multiple cell types including neurons, astrocytes, and oligodendrocytes produce and are responsive to neurotrophins, suggesting autocrine or paracrine function. Microglia both elaborate and respond to trophins. BDNF and NT-3 significantly increased $\left[{ }^{3} \mathrm{H}\right]$ thymidine incorporation in cells grown in serum-free medium, whereas NGF was ineffective, suggesting selectivity in the responsiveness to trophins. Moreover, in the presence of serum, NT-3 increased total cell number, indicating that the trophin, together with factor(s) present in serum, sustains proliferation of microglia. Increases in $\left[{ }^{3} \mathrm{H}\right]$ thymidine incorporation may be attributable to stimulation of cell division or, alternatively, to promotion of mitotic cell survival. Mitogens increase the ratio of mitotic cells to total cells (labeling index), whereas trophins do not affect this ratio, because they sustain mitotic as well as nonmitotic cell survival (DiCicco-Bloom et al., 1988, 1993). Our studies suggest that NT-3 exerts both mitogenic and trophic effects on microglia: the trophin increases the labeling index and prevents death of cells cultured for $72 \mathrm{hr}$. The mechanism of NT-3dependent microglial proliferation is not yet clear. NT-3 may induce microglial division directly, or it may promote the secretion of factors that are microglial mitogens.

Induction of microglia/macrophage proliferation by neurotrophins may be important during development. An increase in brain macrophages is observed during developmental periods when cell death or synaptic elimination occurs (Milligan et al., 1991). This has been associated with increased phagocytic activity and clearance of cellular debris (Hume et al., 1983; Killackey, 1984; Wong and Hughes, 1987; Ferrer et al., 1990). Our results indicate a remarkable increase in phagocytic activity of microglia exposed to NT-3. By inducing microglial proliferation and phagocytic activity simultaneously, neurotrophins may accelerate the clearance of cellular debris and contribute to the formation of brain cytoarchitecture. Such mechanisms may play an important role not only in brain development, but also in recovery from injury.

\section{REFERENCES}

Arenas E, Persson H (1994) Neurotrophin-3 prevents the death of adult central noradrenergic neurons in vivo. Nature 367:368-370. 
Barde YA, Edgar D, Thoenen H (1982) Purification of a new neurotrophic factor from mammalian brain. EMBO J 1:549-553.

Barres BA, Raff MC, Gaese F, Bartke I, Dechant G, Barde Y-A (1994) A crucial role for neurotrophin-3 in oligodendrocyte development. Nature 367:371-375.

Berkemeier LR, Winslow JW, Kaplan DR, Nikolics K, Goeddel DV, Rosenthal A (1991) Neurotrophin-5: a novel neurotrophic factor that activates trk and trk B. Neuron 7:857-866.

Bottenstein JE, Sato GH (1979) Growth of rat neuroblastoma cell line in serum-free supplemented medium. Proc Natl Acad Sci USA 76:514-571.

Chomzynski P, Sacchi N (1987) Single step method of RNA isolation by acid guanidinium thiocyanate-phenol-chloroform extract. Anal Biochem 162:156-169.

Collazo D, Takahashi H, McKay DG (1992) Cellular targets and trophic functions of neurotrophin-3 in the developing rat hippocampus. Neuron 9:643-656.

Davies $\Lambda \mathrm{M}$, Horton $\Lambda$, Burton LE, Schmelzer C, Vandlen R, Rosenthal A (1993) Neurotrophin-4/5 is a mammalian-specific survival factor for distinct populations of sensory neurons. J Neurosci 13:4961-4967.

Dickson DW, Sunhee CL, Mattiace LA, Yen SHC, Brosnan C (1993) Microglia and cytokines in neurological disease, with special reference to AIDS and Alzheimer's disease. Glia 7:75-83.

DiCicco-Bloom EM, Black IB (1988) Insulin growth factors regulate the mitotic cycle in cultured rat sympathetic neuroblasts. Proc Natl Acad Sci USA 85:4066-4070.

DiCicco-Bloom EM, Friedman WJ, Black IB (1993) NT-3 stimulates sympathetic neuroblast proliferation by promoting precursor survival Neuron 11:1101-1111

Dijkstra CD, Dopp EA, Joling P, Kraal G (1985) The heterogeneity of mononuclear phagocytes in lymphoid organs: Distinct macrophage subpopulations in the rat recognized by monoclonal antibodies ED1, ED2 and ED3. Immunology 54:589-599.

Elkabes S, Dreyfus CF, Schaar DG, Black IB (1994) Embryonic sensory development: local expression of neurotrophin-3 and target expression of nerve growth factor. J Comp Neurol 341:204-213.

Elkabes S, Schaar DG, Dreyfus CF, Black IB (1995) Developmental regulation of neurotrophin-3 and trk $\mathrm{C}$ splice variants in optic nerve glia, in vivo. Neuroscience 66:879-889.

Frnfors P, Thanez. C, Fhendal T, Olson I, Persson H (1990) Molecular cloning and neurotrophic activities of a protein with structural similarities to nerve growth factor: developmental and topographic expression in the brain. Proc Natl Acad Sci USA 87:5454-5458.

Ferrer I, Bernet E, Soriano E, del Rio T, Fonseca M (1990) Naturally occurring cell death in the cerebral cortex of the rat and removal of dead cells by transitory phagocytes. Neuroscience 39:451-458.

Friedman WJ, Ernfors P, Persson H (1991) Transient and persistent expression of NT-3 and HDNF mRNA in the rat brain during postnatal development. J Neurosci 11:1577-1584.

Flaris NA, Densmore TL, Molleston MC, Hickey WF (1993) Characterization of microglia and macrophages in the central nervous system of rats: definition of the differential expression of molecules using standard and novel monoclonal antibodies in normal CNS and in four models of parenchymal reaction. Glia 7:34-40.

Fulcrand J, Privat A (1977) Neuroglial reactions secondary to Wallerian degeneration in the optic nerve of the postnatal rat: ultrastructural and quantilative sludy. J Comp Neurol 176:189-224.

Giulian D, Ingeman JE (1988) Colony-stimulating factors as promoters of ameboid microglia. J Neurosci 8:4707-4717.

Giulian D, Baker TJ (1986) Characterization of ameboid microglia isolated from developing mammalian brain. J Neurosci 6:2163.

Giulian D, Young DG, Woodward J, Brown DC, Lachman LB (1988) Interleukin-1 is an astroglial growth factor in the developing brain. J Neurosci 8:709-714.

Giulian D, Chen J, Ingeman JE, George JK, Noponen M (1989) The role of mononuclear phagocytes in wound healing after traumatic injury to adult mammalian brain. J Neurosci 9:4416-4429.

Giulian D (1990) Microglia, cytokines, and cytotoxins: modulators of cellular responses after injury to the central nervous system. J Immunol Immunopharmacol 10:15-21.

Giulian D, Vaca K, Corpuz M (1993) Brain glia release factors with opposing actions upon neuronal survival. $\mathbf{J}$ Neurosci 13:29-37.

Graeber MB, Streit WJ, Kreutzberg GW (1988) Axotomy of the rat facial nerve leads to increased CR3 complement receptor expression by activated microglial cells. J Neurosci Res 21:18-24.
Graeber MB, Streit WJ, Kreutzberg GW (1989) Identity of ED2-positive perivascular cells in rat brain. $\mathrm{J}$ Neurosci Res 22:103-106.

Hamburger V, Brunso-Bechtold JK, Yip JW (1981) Neuronal death in the spinal ganglia of the chick embryo and its reduction by ncrve growth factor. J Neurosci 1:60-71.

Hamilton SP, Leonard HR (1994) Stimulation of in vitro myelin synthesis by microglia. Glia 11:326-335.

Henderson CE, Camu W, Mettling C, Gouin A, Poulsen K, Kaihaloo M, Rullamas J, Evans T, McMahon SB, Armanini MP, Berkemeier L, Phillips HS, Rosenthal A (1993) Neurotrophins promote motor neuron survival and are present in embryonic limb bud. Nature $363: 266-270$

Hetier E, Ayala J, Denefle P, Bousseau A, Rouget P, Mallat M, Prochiantz A (1988) Brain macrophages synthesize interleukin-1 and interleukin-1 mRNAs in vitro. J Neurosci Res 21:391-397.

Hickey WF, Kimura H (1988) Perivascular microglial cells of the CNS are bone marrow derived and present antigen in vivo. Science 239:290-292.

Hohn A, Leibrock J, Bailey K, Barde Y-A (1990) Identification and characterization of a novel member of the nerve growth factor/brain derived neurotrophic factor family. Nature 344:339-341.

Hume DA, Perry VH, Gordon S (1983) Immunohistochemical localization of a macrophage-specific antigen in develuping mouse retina: phagocytosis of dying neurons and differentiation of microglial cells to form a regular array in the plexiform layers. J Cell Biol 97:253-257.

Killackey HP (1984) Glia and the elimination of transient cortical projections. Trends Neurosci 7:225-226.

Lawson LJ, Perry VH, Dri P, Gordon S (1990) Heterogeneity in the distribution and morphology of microglia in the normal adult mouse brain. Neuroscience 39:151-170.

Lee LN, Yokoyama M, Black IB, Drcyfus CF (1994) Neurotrophic regulation of oligodendrocyte development and function. Soc Neurosci Abstr 20:693.

Levi-Montalcini R, Angeletti PU (1968) Nerve growth factor. Physiol Rev 48:534-569.

Lindholm P, Heumann M, Meyer M, Thoenen H (1988) Interleukin-1 regulates synthesis of nerve growth factor in non-neuronal cells of rat sciatic nerve. Nature 330:658-659.

Maisonpierre PC, Belluscio L, Squinto S, Ip NY, Furth ME, Lindsay RM, Yancapoulos GD (1990) Neurotrophin-3: a new neurotrophic factor related to NGF and BDNF. Science 247:1446-1451.

Mallat M, Houlgatte R, Brachet P, Prochiantz A (1989) Lipopolysaccharide-stimulated rat brain macrophages release NGF in vitro. Dev Biol 133:309-311.

McCarthy KD, DeVellis J (1980) Preparation of separate astroglial and oligodendroglial cell cultures from rat cerebral tissue. J Cell Biol 85: 890-902.

McGeer PL, Itagaki S, Tago H, McGeer EG (1987) Reactive microglia in patients with senile dementia of the Alzheimer type are positive for the histocompatibility glycoprotein HLA-DR. Neurusci Lett 79:195-200.

McGeer PL, Kawamata T, Walker DG, Akiyama H, Tooyama I, McGeer EG (1993) Microglia in degenerative neurological disease. Glia 7:84-92.

Milligan CE, Cunningham TJ, Levitt P (1991) Differential immunochemical markers reveal the normal distribution of brain macrophages and microglia in the developing brain. J Comp Neurol 314:125-135.

Murabe Y, Ibata Y ans Sano Y (1981) Morphological studies on neuroglia. III. Macrophage response and "microgliocytosis" in kainic-acid induced lesions. Cell Tissue Res 218:75-86.

Nagata A, Takei N, Nakajima K, Saito H, Kohsaka S (1993) Microglial conditioned medium promotes survival and development of cultured mesencephalic neurons from embryonic rat brain. J Neurosci Res 34:357-363.

Rappolee DA, Mark D, Banda MJ, Werb Z (1989) Wound macrophages express TGF-alpha and other growth factors in vivo: analysis by mRNA phenotyping. Science 241:708-712.

Righi M, Mori L, DeLibero G, Sironi M, Biondi A, Mantovani A, Donini S, Ricciardi-Castagnoli P (1989) Monokine production by microglia cell clones. Eur J Immunol 19:1443-1448.

Robinson AP, White TM, mason DW (1986) Macrophage heterogeneity in the rat as delineated by two monoclonal antibodies MCR Ox-41 and MRC Ox-42, the latter recognizing complement receptor type 3. Immunology 57:239-247. 
Selmaj KW, Farooq M, Norton WT, Raine CS, Brosnan CF (1990) Proliferation of astrocytes in vitro in response to cytokines: a primary role for tumor necrosis factor. J Immunol 144:129-135.

Shimojo M, Nakajima K, Takei N, Hamanoue M, Kohsaka S (1991) Production of basic fibroblast growth factor in cultured brain microglia. Neurosci Lett 123:229-231.

Stoll G, Trapp BD, Griffin JW (1989) Macrophage function during Wallerian degeneration of the rat optic nerve: clearance of degenerating myelin and Ia expression. $\mathbf{J}$ Neurosci 9:2327-2335.

Streit WJ, Graeber MB (1993) Heterogeneity of microglial and perivascular cell populations: insights gained from the facial nucleus paradigm. Glia 7:68-74.

Streit WJ, Graeber MB, Kreutzberg GW (1989) Expression of Ia antigen on perivascular and microglial cells after sublethal and lethal motor neuron injury. Exp Neurol 105:115-126.

Thery C, Chamak B, Mallat M (1991) Cytotoxic effect of brain macrophages on developing neurons. Eur J Neurosci 3:1155-1164.
Thoenen, Barde Y-A (1980) Physiology of nerve growth factor. Physiol Rev 60:1284-1335.

Vaca K, Wendt E (1992) Divergent effects of astroglia and microglia secretions on neuronal growth and survival. Exp Neurol 118:62-72.

Wong ROL, Hughes A (1987) Role of cell death in the topogenesis of neuronal distributions in the developing cat retinal ganglion cell layer. J Comp Neurol 262:496-511.

Yan Q, Elliott J, Snider WD (1992) Brain-derived neurotrophic factor rescues spinal motor neurons from axotomy-induced cell death. Nature 360:753-759.

Thang I, Schmidt RF, Yan Q, Snider WD (1994) NGF and NT-3 have differing effects on the growth of dorsal root axons in developing mammalian spinal cord. J Neurosci 14:5187-5201.

Zajicek JP, Wing M, Scolding NJ, Compston DAS (1992) Interactions between oligodendrocytes and microglia: a major role for complement and tumor necrosis factor in oligodendrocyte adherence and killing. Brain 115:1611-1631. 